Research Article

\title{
Assessment of prescription writing skills among undergraduate medical students
}

\author{
M. J. Sudha ${ }^{1}$, S. Viveka ${ }^{2}$, S. Remya ${ }^{1}$
}

${ }^{1}$ Associate Professor,

Department of Pharmacology,

${ }^{2}$ Associate Professor,

Department of Anatomy,

Azeezia Institute of Medical

Sciences, Kollam, Kerala, India

Received: 03 June 2016

Accepted: 04 July 2016

*Correspondence to:

Dr. M. J. Sudha,

Email: sudhasudhasudha@ gmail.com

Copyright: (C) the author(s), publisher and licensee Medip Academy. This is an openaccess article distributed under the terms of the Creative Commons Attribution NonCommercial License, which permits unrestricted noncommercial use, distribution, and reproduction in any medium, provided the original work is properly cited.

\begin{abstract}
Background: The existing medical undergraduate curriculum includes training in prescription writing in second phase under pharmacology and Therapeutics. This study evaluates the prescription writing skills of undergraduate medical students and interns and need for emphasis on prescription writing during various phases of learning process in medical undergraduates.

Methods: After obtaining institutional ethics committee approval, we recruited 4th to 8th semester medical undergraduate students and interns into the study, who gave written informed consent. They were given a pilot-tested, preevaluated questionnaire addressing the issues of prescription writing. They were asked to prescribe for a common clinical scenario. Their prescriptions were analysed for various parameters as indicated in WHO guidelines.

Results: Of the 350 medical undergraduate students and interns invited, 281 of them participated in the study. 169 participants $(60.1 \%)$ agree that they have not written a formal prescription to any patient when the questionnaire was administered. 134 participants $(47.6 \%)$ feel that undergraduate training has not prepared them for prescribing properly. $90 \%$ of participants said reinforcing classes during $3^{\text {rd }}, 4^{\text {th }}$ year and during Compulsory Routine Rotatory Internship will be beneficial. Though 220 participants have opined that generic name should be used while prescribing, only 124 have actually used generic names in their prescriptions. Fifteen participants have failed to write the symbol while prescribing. All 121 interns in the study have used brand names while prescribing.

Conclusions: There are widespread lacunae in prescription writing by medical undergraduates. There is perceived need for reinforcement sessions at third and final phase of undergraduate education to address this gap. Most participants opine that clinicians do not discuss this issue during case discussion. There is knowledge and practice gap in using generic names while prescribing.
\end{abstract}

Keywords: Prescription writing, Curriculum change, Medical undergraduates, Clinical discussion

\section{INTRODUCTION}

Prescription writing is one of the important 'core' competency expected from a medical graduate. Decisionmaking and proper transcribing are quintessential attributes of writing an ideal prescription. ${ }^{1}$ The word, 'prescribe' comes from Latin word meaning to write or to designate or order the use of as a remedy. Prescription not only indicates names of drugs, dosage and duration of treatment, but also acts as legal document indicating instructions to patients, pharmacists and contains essential contact information of prescriber and patient. This information may come handy in case of adverse drug event. ${ }^{2}$ Any mistake in writing a proper prescription leads to prescription errors, in turn leading to medication errors. Prescription errors are reported to have a heavy toll in health care. ${ }^{2}$ In United States, prescription errors are eighth leading cause of death. ${ }^{3}$ (Similar data is not available in India). Modifications in medical undergraduate training has shown to have a positive impact in prescription writing skills. ${ }^{4-6}$ 
Prescription writing is taught in second phase of medical education in India. Students will be utilizing this knowledge throughout their life. They start prescribing during their internship. Most of them learn by tedious learn by error methods even though it is taught systematically well in advance during undergraduate training. Generally most learn by observing seniors or when are commanded by seniors. ${ }^{7-10}$

World health organization (WHO) has made few recommendations for optimized effective prescriptions. They are directed towards mentioning professional, patient's identity and details, mode of administration, drug generic names, dosage and frequency of use and duration of treatment. ${ }^{11}$ Care must be taken to avoid any errors in prescribing as it adversely affects the treatment outcome. Therefore, there is need for proper education based intervention to aid improvement in prescribing competency.

With advent of new drugs and formulations, prescribing has become more complicated. Especially in scenarios where there are newer drugs or newer indications for older drugs. Therefore, the prescribers must be very cautious while writing. It serves as a legal document as well.

There are many studies done in past, especially in foreign universities evaluating the prescription writing skills of junior doctors and medical undergraduates. ${ }^{5,6,11-14}$ This study evaluates the prescription writing skills of undergraduate medical students and interns. By analysing their skills we could address the primary question - was systematic training of prescription writing during second phase helpful in third and final year MBBS and internship? If not what can be done to improve prescription writing during these training phases?

The objective of this study was to assess the prescription writing skills among various phases of undergraduate medical students. And to assess the need for emphasis on prescription writing during various phases of learning process in medical undergraduate's.

\section{METHODS}

The design of this study was cross sectional survey.

\section{Inclusion criteria}

Fourth to eight semester medical students and interns.

\section{Exclusion criteria}

Students not willing to participate. Students who did not complete the questionnaire or fill in the prescription.

The study was conducted Azeezia Institute of Medical Sciences.
Azeezia ethics committee approval was obtained prior to initiation of the study. The study duration was May to August 2015.

\section{Tools used}

- $\quad$ Structured questionnaire

- Prescription writing for a specific clinical scenario

- Written informed consent form.

The questionnaire (annexure 1) was pretested in the department of pharmacology with 25 students and questions were standardized. The testing and retesting of the questionnaire was done. The questions were rephrased, reframed, added, and removed from the questionnaire for better comprehension. Then the questionnaire was distributed among intended participants.

The students were invited to take part in this research, after obtaining the written informed consent; the structured questionnaire was distributed to the participants. They were asked to prescribe for a clinical scenario printed in the form after which they would fill in the feedback questionnaire printed on the reverse. The process took around twenty minutes for a participant. The students participated in different batches. In the process, there occurred self-learning and introspection to some extent. After collecting the questionnaire, the students were given a briefing on how to write a proper prescription.

Participants answered a case scenario of acute gastritis and were asked to prescribe drug therapy in a given time. Prescribing knowledge of students was evaluated based on their quality of prescription, compliance with good prescribing pattern and WHO's prescribing indicators. The patient's name, age, and gender; the date of issuance; the symbol Rx; the drug name (legible), dose, and strength; directions for use; the signature of the prescriber, date, and prescriber's registration number and instructions for refills were chosen as nominal variables to assess the completeness of prescriptions.

\section{RESULTS}

A total three hundred and fifty medical undergraduates were approached, out of which 281 students participated in this study, this included 39 from semester 4, 35 from semester 5,37 from semester 6,49 from $8^{\text {th }}$ semester and 121 interns.

Table 1 depicts analysis of feedback questionnaire. Prescription writing is systematically dealt during second year pharmacology teaching, 21 participants $(7.4 \%)$ failed to acknowledge that they have learnt it during their training programme. Fifty participants $(17.8 \%)$ said that there were no questions asked in summative assessment regarding prescription writing, whereas it is actually a part 
of the university requirement for exams and is actually

included in the practical assessment.

Table 1: Tabulation of answers of feedback questionnaire $(\mathbf{n = 2 8 1})$.

\begin{tabular}{|lll|}
\hline Questionnaire & Number & Percentage \\
\hline Number of participants who have - & $\mathrm{N}=281$ & \\
\hline learnt prescription writing previously & 260 & 92.5 \\
\hline Were there any questions in summative assessment regarding prescriptions & 230 & 81.9 \\
\hline Written prescriptions previously & 111 & 39.5 \\
\hline Undergraduate training - prepared you? $^{\text {Clinicians discuss prescription writing }}$ & 146 & 52.0 \\
\hline Prescription writing as part of case discussion & 126 & 44.8 \\
\hline Discussions and writing help for better prescription & 67 & 23.8 \\
\hline Reinforcing classes during ${ }^{\text {rd }}$ and $4^{\text {th }}$ year & 235 & 83.6 \\
\hline Reinforcing classes during CRRI & 253 & 90.0 \\
\hline Trade name or generic name & 254 & 90.4 \\
\hline Provide patient education & $61 / 220$ & $21.7 / 78.2$ \\
\hline Discharge counselling on medication & 241 & 85.8 \\
\hline Special population difficulty & 243 & 86.5 \\
\hline Pharmacist contribute to medication use & 258 & 91.8 \\
\hline Collaboration with pharmacist will enhance safety & 99 & 35.2 \\
\hline Pharmacist - reliable information & 236 & 84.0 \\
\hline Ever dispensed medications & 132 & 47.0 \\
\hline Training in prescribing paediatric drugs & 57 & 20.3 \\
\hline
\end{tabular}

Table 2: Parameters noted in prescription written by participants $(\mathbf{n}=\mathbf{2 8 1})$.

\begin{tabular}{|lll|}
\hline Parameters noted in prescription & Yes & Percentage \\
\hline Date mentioned & 240 & 85.4 \\
\hline Name of doctor mentioned & 187 & 66.5 \\
\hline Address of doctor & 94 & 33.5 \\
\hline Phone number of doctor & 61 & 21.7 \\
\hline Patient name written & 270 & 96.1 \\
\hline Patient address mentioned & 119 & 42.3 \\
\hline Patient phone number & 30 & 10.7 \\
\hline Patient's age & 267 & 95.0 \\
\hline Sex & 249 & 88.6 \\
\hline Weight & 59 & 21.0 \\
\hline Symbol & 266 & 94.7 \\
\hline Frequency written & 254 & 90.4 \\
\hline Duration & 230 & 81.9 \\
\hline Dosage form & 250 & 89.0 \\
\hline Generic & 117 & 41.6 \\
\hline Brand & 164 & 58.4 \\
\hline Dose & 234 & 83.3 \\
\hline Patient instructions & 122 & 43.4 \\
\hline Hand writing & 275 & 97.9 \\
\hline Review & 82 & 29.2 \\
\hline Initials (signature) & 267 & 95.0 \\
\hline Registration number & 158 & 56.2 \\
\hline Instruction to pharmacist & 7 & 2.5 \\
\hline & & \\
\hline
\end{tabular}

169 participants $(60.1 \%)$ agree that they have not written a formal prescription to any patient when the questionnaire was administered. 134 participants (47.6\%) feel that undergraduate training has not prepared them for prescribing properly. Nearly 126 participants agreed that clinicians discuss prescription writing but only $23.8 \%$ agree that these discussions were part of clinical case discussions. Fifty-four participants said that discussions happen more often. Only nine participants feel that such discussions are regular. This implies that training of prescription writing is more of a non-case discussion event. More than three fourth of participants $(235,83.6 \%)$ equivocally accept that such discussions and on hand training by clinicians help them in better prescription writing. $90 \%$ of participants said reinforcing classes during $3^{\text {rd }}, 4^{\text {th }}$ year and during compulsory rotatory residential internship will be beneficial.

220 participants $(78.2 \%)$ says generic name while prescribing but 61 participants preferred trade name. Most participants agree that they should educate patients $(85.8 \%)$ and counsel while discharging $(86.5 \%)$.

\section{Analysis of prescriptions (Figure 2)}

Handwriting was legible and comprehendible in $98 \%$ of the prescriptions. Though 220 participants have opined that generic name should be used while prescribing, only 124 have actually used generic names in their 
prescriptions (Figure 1). Fifteen participants have failed to write the symbol while prescribing.

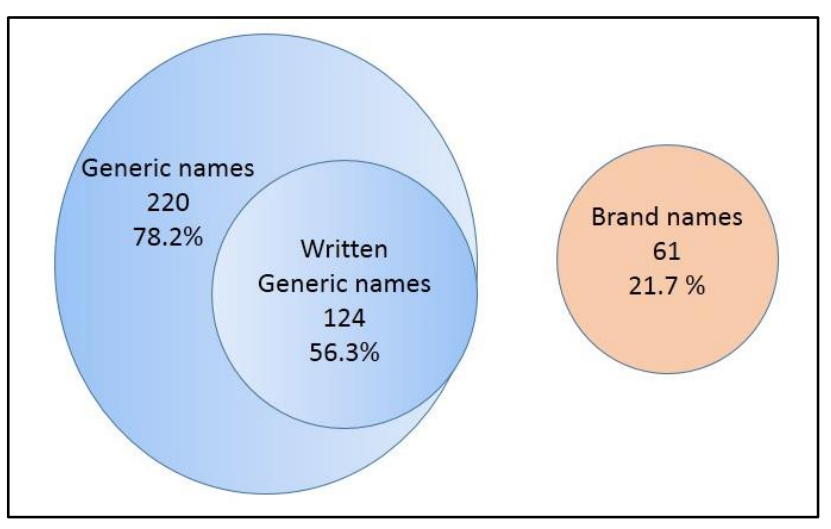

Figure 1: Graphical representation of number participants using generic names and brand names with percentages. $n=281$.

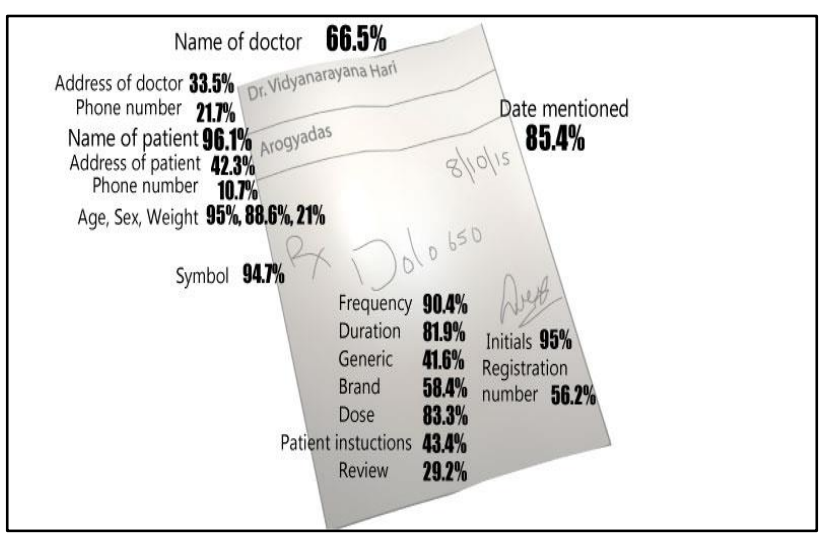

Figure 2: Schematic representation of parameters noted in a prescription writing by medical undergraduates. Numbers given next to parameters indicates percentage of students writing them correctly. Prescribers name, patient name and drugs in prescription are symbolic, not actual. $n=281$.

All 121 interns in the study have used brand names while prescribing. Only twenty-eight interns have written their registration numbers while prescribing. $14.6 \%$ participants failed to mention the date. $33 \%$ failed to mention the name of the doctor and $78.3 \%$ failed to mention the phone number of the doctor. Though $85 \%$ opine that patient's need to be instructed, only $43.4 \%$ actually written such patient instructions. $70.8 \%$ fail to write review details (Table 2).

\section{DISCUSSION}

Prescribing drugs for common ailments is an important core competency of medical undergraduate. ${ }^{15,16}$ It involves a mixture of knowledge, judgement and skills. ${ }^{17}$ The existing medical undergraduate medical curriculum includes prescription training in second phase under pharmacology. Even though all medical undergraduates get training regarding prescription writing during their second phase of MBBS, in this study, we noted $7.4 \%$ of the participants saying they never had such training. This depicts either careless attitude of the students during their formative training or subtleness of such training. There is some evidence suggesting improvement in training. ${ }^{18}$ Many studies opine that once the newly qualified doctors exposed to workplace prescription writing, they retrospectively feel that there was insufficient emphasis on practical aspects of writing prescription in undergraduate curriculum. ${ }^{15,19}$ Interns share this view as well. ${ }^{20}$ There is growing evidence that, prescription errors are increasing and are often caused by inadequate training in prescription writing. ${ }^{2,21}$ With better training and exposure of medical students this issue can be addressed. ${ }^{5,22}$

\section{The main findings of this study are}

- Though every medical undergraduate gets trained in prescription writing, they are not confident of writing,

- Prescribing was very rarely practiced prior to graduation,

- Less than half the respondents agree that clinicians discuss prescription writing skills,

- Most feel that they need reinforcement sessions at third and final phase of medical training,

- Most feel that they need reinforcement session at the beginning of internship.

- Most participants felt that there difficulty in prescribing for special groups.

Results of assessment of prescription writing skills at various stages of medical undergraduate training showed similarity to many previous studies done in India and neighbouring countries. ${ }^{1,7,8,23-27}$ Illegible handwriting may lead to serious medication error and has been reported in many of the previous studies. ${ }^{28-31}$ Contrastingly, in our study, handwriting of most participants was legible and comprehendible.

Information regarding the prescriber was missing in many prescriptions. Participants in many studies, including in our study, failed to mention their phone numbers and addresses. $^{24}$ Such contact details may be lifesaving if patient faces adverse drug events. In India, it is important to mention the registration number in each prescription. The lack of the display of registration number may amount to a serious negligence on the part of the doctor. In our study, all interns failed to depict a slot for registration numbers.

Use of generic names is universally advocated while prescribing. But most previous studies report that many doctors write brand names. ${ }^{32,33}$ In our study, even though many participants knew that generic names to be used (according questionnaire analysis), they wrote brand names while prescribing. Various studies have suggested assisted e-learning modules brings about positive change 
in undergraduates regarding prescription writing. ${ }^{28,34}$ Educational training programs have resulted in significant behavioural changes. ${ }^{31,35}$ Good prescribing habits reinforced by practical example as in good bed side clinical class or OPD training is essential to bring a change in prescription writing skills in medical graduates.

\section{Implications}

This study evaluates the difficulties in learning and recollecting prescription writing skills. By addressing such issues, it can be assumed that students will be able to prescribe with minimal errors/without any errors. Knowledge about students' perception regarding reinforcements during third and fourth years of training or inclusion during case discussion is of great value for the regulatory/scientific body which designs or formulates the medical curriculum. Clinical pharmacologists should play an essential role in training of proper prescription writing skills among medical graduates. Prescription writing should be identified as an important core learning competency. It runs vertically through the medical curricula integrating with relevant horizontal modules.

\section{CONCLUSION}

There are widespread lacunae in prescription writing by medical undergraduates. There is perceived need for reinforcement sessions at third and final phase of undergraduate education to address this gap. Most participants opine that clinicians do not discuss this issue during case discussion. There is knowledge and practice gap in using generic names while prescribing. There is discrepancy in patient instructions, discharge advice and contact details of prescriber in case of adverse drug event.

\section{ACKNOWLEDGMENTS}

This project was done as a part of Fellowship In Medical Education (FIME), an advanced faculty training program by Medical Council of India (MCI) under guidance of Dr. Sajith Kumar, Convener, Nodal centre for faculty development, Government Medical College, Kottayam, Kerala. We would like to acknowledge the entire nodal centre faculty for providing support and necessary guidance. Author thanks all medical undergraduates and interns who took part in the study, Dr Sujathan G, Principal and management of Azeezia Institute of Medical Sciences for permitting us to conduct the study.

Funding: No funding sources

Conflict of interest: None declared

Ethical approval: The study was approved by the Institutional Ethics Committee

\section{REFERENCES}

1. Akram A, Mohamad N, Meerah TSM, ZamZam R, Abdullah D. A pilot study-an action research to acquire clinical skill. Procedia Soc Behav Sci. 2012;60:236-40.

2. Dean B, Schachter M, Vincent C, Barber N. Causes of prescribing errors in hospital inpatients: a prospective study. Lancet Lond Engl. 2002;359(9315):1373-8.

3. America C. on Q of HC in, Medicine I of To Err Is Human: building a safer health system. National Academies Press; 2000:312.

4. Al Khaja KAJ, James H, Sequeira RP. Effectiveness of an educational intervention on prescription writing skill of preclerkship medical students in a problembased learning curriculum. J Clin Pharmacol. 2013;53(5):483-90.

5. Vollebregt JA, Metz JCM, de Haan M, Richir MC, Hugtenburg JG, de Vries TPGM. Curriculum development in pharmacotherapy: testing the ability of preclinical medical students to learn therapeutic problem solving in a randomized controlled trial. $\mathrm{Br} \mathbf{J}$ Clin Pharmacol. 2006;61(3):345-51.

6. Garbutt JM, DeFer TM, Highstein G, McNaughton C, Milligan P, Fraser VF. Safe prescribing: an educational intervention for medical students. Teach Learn Med. 2006;18(3):244-50.

7. Banerjee I, Bhadury T. Prescribing pattern of interns in a primary health center in India. $\mathrm{J}$ Basic Clin Pharm. 2014;5(2):40-3.

8. Pati R. Prescribing pattern among medical interns at the rural health centres of a medical college, Manipal, Karnataka. Indian J Community Med. 2004;29(3):128.

9. Bhartiy SS, Shinde M, Nandeshwar S, Tiwari SC. Pattern of prescribing practices in the Madhya Pradesh, India. Kathmandu Univ Med J KUMJ. 2008;6(1):55-9.

10. Rehan HS, Lal P. Drug prescribing pattern of interns at a government healthcare centre in northern India. Trop Doct. 2002;32(1):4-7.

11. de Vries TPGM, Henning RH, Hogerzeil HV, Fresle DA. Guide to good prescribing - a practical mannual. Geneva: World Health Organization Action Programme on Essential Drugs; 2012. Available at http://apps.who.int/medicinedocs/pdf/whozip23e/who zip23e.pdf.

12. Scobie SD, Lawson M, Cavell G, Taylor K, Jackson SHD, Roberts TE. Meeting the challenge of prescribing and administering medicines safely: structured teaching and assessment for final year medical students. Med Educ. 2003;37(5):434-7.

13. Langford NJ, Martin U, Kendall MJ, Ferner RE. Medical errors. Medical schools can teach safe drug prescribing and administration. BMJ. 2001;322(7299):1424.

14. Aronson JK, Henderson G, Webb DJ, Rawlins MD. A prescription for better prescribing. BMJ. 2006;333(7566):459-60.

15. Heaton A, Webb DJ, Maxwell SRJ. Undergraduate preparation for prescribing: the views of $2413 \mathrm{UK}$ medical students and recent graduates. $\mathrm{Br} \mathrm{J}$ Clin Pharmacol. 2008;66(1):128-34. 
16. Kripalani S, Bussey-Jones J, Katz MG, Genao I. A prescription for cultural competence in medical education. J Gen Intern Med. 2006;21(10):1116-20.

17. Ross S, Maxwell S. Prescribing and the core curriculum for tomorrow's doctors: BPS curriculum in clinical pharmacology and prescribing for medical students. Br J Clin Pharmacol. 2012;74(4):644-61.

18. Kilminster S, Zukas M, Quinton N, Roberts $T$. Preparedness is not enough: understanding transitions as critically intensive learning periods. Med Educ. 2011;45(10):1006-15.

19. Tobaiqy M, McLay J, Ross S. Foundation year 1 doctors and clinical pharmacology and therapeutics teaching. A retrospective view in light of experience. Br J Clin Pharmacol. 2007;64(3):363-72.

20. Coombes ID, Stowasser DA, Coombes JA, Mitchell C. Why do interns make prescribing errors? A qualitative study. Med J Aust. 2008. Available at https://www.mja.com.au/journal/2008/188/2/why-dointerns-make-prescribing-errors-qualitative-study.

21. Leape LL, Bates DW, Cullen DJ, Cooper J, Demonaco HJ, Gallivan T, et al. Systems analysis of adverse drug events. ADE Prevention Study Group. JAMA. 1995;274(1):35-43.

22. Midlöv P, Bondesson A, Eriksson T. Effects of educational outreach visits on prescribing of benzodiazepines and antipsychotic drugs to elderly patients in primary health care in southern Sweden. Fam Pr. 2006;23:60-4.

23. Upadhyaya P, Seth V, Sharma M, Ahmed M, Moghe VV, Khan ZY, et al. Prescribing knowledge in the light of undergraduate clinical pharmacology and therapeutics teaching in India: views of first-year postgraduate students. Adv Med Educ Pr. 2012;3:4753.

24. Phalke VD, Phalke DB, Syed MMA, Mishra A, Sikchi S, Kalakoti P. Prescription writing practices in a rural tertiary care hospital in Western Maharashtra, India. Australas Med J. 2011;4(1):4-8.

25. Rauniar GP, Roy RK, Das BP, Bhandari G, Bhattacharya SK. Prescription writing skills of preclinical medical and dental undergraduate students. JNMA J Nepal Med Assoc. 2008;47(172):197-200.
26. Akram A, ZamZam R, Mohamad NB, Abdullah D, Meerah SM. An assessment of the prescribing skills of undergraduate dental students in Malaysia. J Dent Educ. 2012;76(11):1527-31

27. Jain A, Bhaskar D, Gupta D, Yadav P, Dalai D, Jhingala $\mathrm{V}$, et al. Drug prescription awareness among the $3^{\text {rd }}$ year and final year dental students: a crosssectional survey. J Indian Assoc Public Heal Dent. 2015;13(1):73.

28. Hester DO. Do you see what I see? Illegible handwriting can cause patient injuries. J Ky Med Assoc. 2001;99(5):187.

29. Winslow EH, Nestor VA, Davidoff SK, Thompson PG, Borum JC. Legibility and completeness of physicians' handwritten medication orders. Heart Lung J Crit Care. 1997;26(2):158-64.

30. Boehringer PA, Rylander J, Dizon DT, Peterson MW. Improving the quality of the order-writing process for inpatient orders in a teaching hospital. Qual Manag Health Care. 2007;16(3):215-8.

31. Meyer TA. Improving the quality of the order-writing process for inpatient orders and outpatient prescriptions. Am J Heal-Syst Pharm AJHP Off J Am Soc Heal-Syst Pharm. 2000;57(Suppl 4):S18-22.

32. Irshaid YM, Al Homrany M, Hamdi AA, AdjeponYamoah KK, Mahfouz AA. Compliance with good practice in prescription writing at outpatient clinics in Saudi Arabia. East Mediterr Heal J Rev Santé Méditerranée Orient Al-Majallah Al-Ṣiḥ̣īyah LiSharq Al-Mutawassit. 2005;11(5-6):922-8.

33. Pandey AA, Thakre SB, Bhatkule PR. Prescription analysis of pediatric outpatient practice in Nagpur city. Indian J Community Med Off Publ Indian Assoc Prev Soc Med. 2010;35(1):70-3.

34. Ter Wee RJ, van der Kleijn E, Brenninkmeijer RF, Holmberg N. Development of an electronic prescription processing option: an aid for general practice. $\mathrm{Br} \quad \mathrm{J}$ Gen $\operatorname{Pr} \quad \mathrm{J} \quad \mathrm{R}$ Coll Gen Pr. 1991;41(345):151-4.

35. Oshikoya K, Bello J, Ayorinde E. Prescribing knowledge and skills of final year medical students in Nigeria. Indian J Pharmacol. 2008;40(6):251.

Cite this article as: Sudha MJ, Viveka S, Remya S. Assessment of prescription writing skills among undergraduate medical students. Int J Basic Clin Pharmacol 2016;5:1586-93. 


\section{Annexures}

\section{Annexure 1: Questionnaire and prescription writing case used in the study}

Questionnaire

Name
Date

Semester

1. Have you learnt the prescription writing previously? - Yes $\square$ / No

2. Were there any questions in your summative assessment of pharmacology regarding prescription writing? - Yes $\square /$ No $\square$

3. Have you written a prescription previously for any common ailments? - Yes $\square /$ No

4. Do you feel that your undergraduate training has prepared you to prescribe? - Yes $\square$ / No

5. Do clinicians discuss prescription writing as a part of case discussion? - Yes $\square$ / No

6. If Yes, how often? A) very rare

B) rare C) often

D) regular

7. Have you written any prescriptions in the case discussion classes? - Yes $\square /$ No

8. If Yes, how many? Number-

9. Do such discussions and writing help in efficient prescribing? $\quad$ - Yes $\square$ / No

10. Do you need any reinforcing classes during third and fourth year of training for prescription writing?

- Yes $\square /$ No $\square$

11. Do you need any reinforcing Classes during CRRI - Yes $\square /$ No

12. Do you prefer using trade name $\square$ or generic name $\square$ while prescribing a drug?

13. Do you Provide patient education on their medicines - Yes $\square$ / No

14. Do you Provide discharge counseling on medication use - Yes $\square$ / No

15. Do you find it difficult to prescribe for special population (like-Pregnant, children, liver failure, renal failure, heart failure etc.) - Yes $\square /$ No $\square$ 
16. Do you get pharmacist to contribute to medication use in your practice? - Yes

17. Do you think collaboration with pharmacists will enhanced drug related patient safety? - Yes $\square /$ No

18. Do you think pharmacists are a reliable source of clinical drug information? - Yes $\square /$ No $\square$

19. Have you ever Dispensed medication - Yes $\square /$ No $\square$

20. Did you have enough training about pediatric drugs? - Yes $\square$ / No

21. Where do you obtain drug related data (Source of drug information)

- CIMS, physicians' desk reference, Drug index, MIMS

- Indian National formulary, Indian Pharmacopeia, British National Formulary, Text books

\section{Annexure 2: Prescription writing questions}

\section{Write prescription for following case scenario:}

Abenizer, aged 40 years presented with upper abdominal pain and severe retching. He was diagnosed to have acute gastritis. 